\title{
Residency Training: A practical guide for medical students who are planning a future in neurology
}

James J. Gugger, MD, PharmD, * Lauren Bowen Reoma, MD,* Madhu Soni, MD, Valerie Olson, MD, PhD, Ezgi Tiryaki, MD, and James M. Noble, MD, MS, on behalf of the AAN Undergraduate Education Subcommittee Neurology ${ }^{\circledR}$ 2020;94:673-677. doi:10.1212/WNL.0000000000009247

\section{Correspondence}

Dr. Gugger

james.gugger@

pennmedicine.upenn.edu

\begin{abstract}
Medical students choose neurology for many reasons, including interest in neuroscience, the intellectual challenge of diagnosing and treating disorders of the nervous system, and the opportunity for continuity of care. Neurologists have great flexibility in choice of practice environment, ranging from an exclusively inpatient setting to a strictly clinic-based practice. The purpose of this article is to provide practical, actionable, systematic advice for medical students at every level of training on how to prepare for a neurology residency application and a career in neurology. To this end, we include a timeline designed to guide students' efforts throughout their medical school education. These recommendations incorporate the viewpoints of key participants in many aspects of medical student and resident neuroscience education. The timeline and recommendations outline a suggested early, proactive approach, but should not discourage students from considering neurology at a later point in their training. Neurology remains an inclusive specialty that welcomes students of all backgrounds and offers a rewarding career in one of the most exciting fields in medicine.
\end{abstract}

\section{Introduction}

Neurology is an increasingly attractive career choice. Data from the National Resident Matching Program show a $48 \%$ increase in the total number of applicants matching into neurology (child and adult) between 2015 and 2019. ${ }^{1}$ While guidelines exist for educators, ${ }^{2-4}$ there is a dearth of guidance for students preparing for a career in neurology. General guidance regarding career and Electronic Residency Application Service (ERAS) application preparation is helpful, but additional resources and guidance are often sought for students considering a career in neurology. The purpose of this article is to provide practical, actionable, systematic advice for students at every level of training on how to prepare for residency application and a career in neurology. To this end, we include a timeline designed to guide students' efforts throughout their medical school education. These recommendations incorporate the viewpoints of key participants in many aspects of medical student and resident neuroscience education.

\section{Training timeline}

For the neurologist-to-be, we provide guidelines that allow students to explore their interest in neurology (figure). The reader should keep in mind that these are only guidelines and many pathways can lead to a neurology residency. Neurology remains an inclusive specialty that welcomes students of all backgrounds. As an example, for non-US citizens and graduates of international medical schools who successfully matched in 2019, neurology was among the top 5 specialties. ${ }^{1}$ 


\section{Glossary}

AAN = American Academy of Neurology; ANA = American Neurological Association; ERAS $=$ Electronic Residency Application Service; LOR = letter of recommendation; SIGN = Student Interest Group in Neurology.

\section{Pre-clerkship period}

The pre-clerkship years of medical school are an excellent time to explore student interest groups for various specialties. Some schools may have independent specialty interest groups in neurology. The Student Interest Group in Neurology (SIGN), which is supported by the American Academy of Neurology (AAN), is the largest of these. SIGN programs are under the direction of student leaders who typically plan a series of meetings with faculty, residents, and local neurologic advocacy groups; programs are intended to help orient students to career options in clinical neuroscience and in some instances develop early experiential learning about neurologic disorders before they are presented in traditional curricula. Students attending schools without a chapter may apply to the AAN to establish one. More information is available online. ${ }^{5}$ This is also a good time to identify a mentor in neurology and participation in SIGN is an excellent way to do this. Identification of a longitudinal mentor early in medical school is an effective way to generate interest in the specialty. ${ }^{6,7}$ Students are encouraged to join the AAN or the American Neurological Association (ANA), a society geared more to the academic neurologist, or both. Membership in these organizations offers a variety of benefits including educational and career resources, information about research grant applications, and scholarships.

Neuroscience research is encouraged and, depending on the structure of the medical school curriculum, ideally conducted during the pre-clerkship period (figure). An in-depth experience may make the student more attractive to residency program directors; however, it is by no means essential for a competitive residency application and does not replace solid clinical experience and good academic performance. As a means to both strengthen their application and inform career decisions, students less inclined to pursue research should consider projects in community outreach, quality improvement, public health education, and global health initiatives. ${ }^{8}$ An in-depth experience in one of these activities may make a student just as attractive as a student with significant research experience, if not more so. Whatever the experience, the commitment, time spent, and lessons learned through a dedicated project can demonstrate to program directors that the student displays the characteristics of intellectual curiosity, initiative, responsibility, and the ability to work independently as well as with a team.

If students are planning to perform research, they should discuss applying for funding with their mentor: examples of financial support include internal funds or funding from private, foundational, or NIH-based resources (e.g., short-term training grants). The AAN also offers a Medical Student Research Scholarship. Near the conclusion of the research experience, students should discuss presenting their results with their mentor. There are multiple avenues to present one's research: the student may want to submit an abstract (i.e., for a poster presentation) for the AAN, ANA, or neurology subspecialty society annual meeting, at their medical school's research day, or at a state neurologic society.

For those students who are seriously considering an academic career and are not on an $\mathrm{MD} / \mathrm{PhD}$ track, there may be additional research opportunities later in medical school. The NIH offers 1-year research programs, as do many academic centers and some private foundations such as the National Multiple Sclerosis Society. However, it is by no means necessary to dedicate a year to research. Indeed, trainees may develop more informed research questions following advanced clinical experiences during and after residency.

Medical students are encouraged to attend local, regional, and national meetings to expand their knowledge and network with other professionals in neurology (figure). The AAN and ANA organize 2 large annual meetings that provide broad exposure to clinical neurology. It is worthwhile to attend one of these conferences during medical school, if possible. The AAN provides financial support to students, including the competitive Medical Student Scholarship to the annual meeting. Medical schools and neurology departments may also have funding. The ANA annual meeting is often smaller than the AAN meeting and can offer closer networking opportunities. The ANA provides financial support to students whose abstracts are accepted for presentation at the meeting. There are many neurology subspecialty societies that host annual meetings, which may be of interest to the student with a specific subspecialty interest.

\section{Clinical training in neurology: clerkships}

Planning the sequence of clerkships may be helpful in preparing for residency application. Generally, most students will try to place their intended specialty midway through the year. Doing the neurology clerkship last may delay securing letters of recommendation (LORs) prior to the application deadline. Conversely, taking the neurology clerkship first might mean spending more time acclimating to the clinical environment. It helps to take internal medicine (or pediatrics for child neurology) prior to the neurology clerkship as knowing the basics of internal medicine or pediatrics will give the student more confidence and applicable foundational knowledge.

The neurology clerkship is a pivotal experience. The main objectives include learning the neurologic examination, practicing localization, and familiarizing oneself with neurologic conditions. ${ }^{4}$ Students should practice using the tools of the trade: the reflex hammer, $128-\mathrm{Hz}$ tuning fork, and an ophthalmoscope (whether borrowed or purchased); the more opportunities to practice the neurologic examination and 


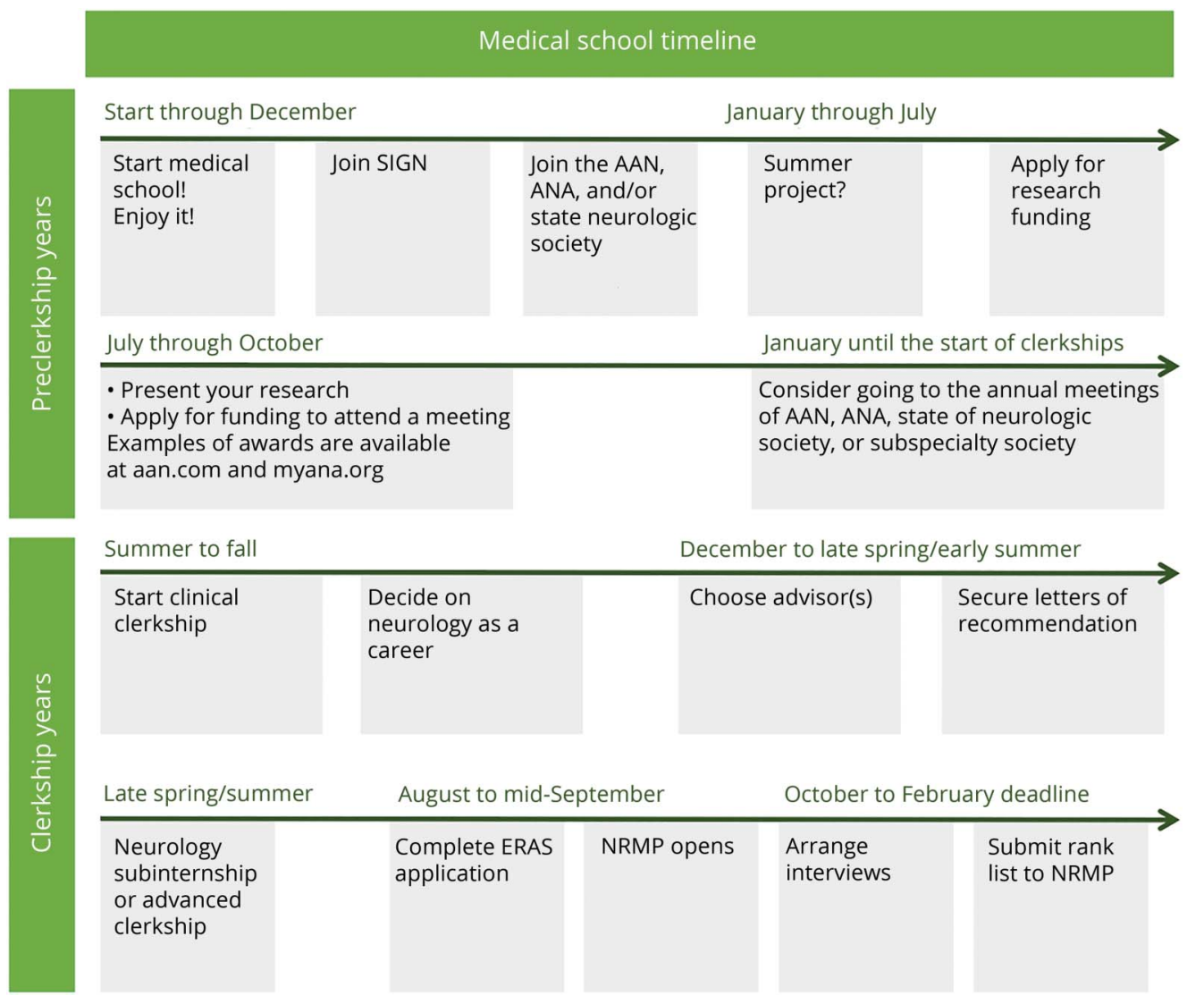

Medical school timeline beginning with the first year of medical school and ending with submission of the rank list in the final year of medical school. AAN $=$ American Academy of Neurology; ANA = American Neurological Association; ERAS = Electronic Residency Application Service; NRMP = National Resident Matching Program; SIGN = Student Interest Group in Neurology.

localization, the better. If not already part of the clerkship curriculum, students may want to take a day or 2 to explore subspecialty areas of neurology: examples include, but are not limited to, observing the specialized examination techniques of the neuro-ophthalmologist or movement disorder specialist in clinic, shadowing the neuromuscular specialist as he or she performs EMGs, or attending an epilepsy surgical conference.

The amount of exposure to child neurology in the neurology clerkship varies by institution; however, the clerkship typically provides exposure primarily to adult conditions. At some institutions, part of the clerkship or the entire clerkship may be dedicated to child neurology, whereas at others, it may not be offered at all. ${ }^{9}$ For the student interested in child neurology, an elective in this area may be necessary.

\section{Elective clerkships}

Elective clerkships principally serve to round out the student's knowledge base and expand his or her skill set in advance of internship. This year is an opportunity for students to gain knowledge and skills in specialties they may no longer be formally exposed to as they move forward in their careers, and the time should not be solely dedicated to neurology clerkships.
Exposure to areas of medicine that overlap with neurology can broaden a student's understanding of the pathophysiology and presentation of neurologic disorders. Students are also encouraged to complete a neurology subinternship or an advanced elective in neurology as early as possible in the fourth year. During this time, students may want to explore subspecialty aspects of neurology, including better understanding what procedures may be performed by a neurologist or by others to inform clinical practice.

For those students looking to secure a residency position in a highly competitive program, an away rotation in neurology at that institution may be advantageous and usually can be arranged through the Visiting Student Application Service. This rotation is viewed as an audition for residency and will allow the student to get a better idea of what it would be like to be a resident at the institution. It should be noted that this is by no means a mandatory experience and does not preclude one from obtaining a spot at a competitive residency program. There is also the issue of financing travel and accommodations at a visiting institution. One resource to consider is the AAN Visiting Medical Student Scholarship Program and some host programs offer housing options on campus. 
With regard to grades, it is always most important to learn well from each clerkship and develop a solid clinical foundation; performing well in the neurology and medicine clerkships is especially important. In addition, the US Medical Licensing Examination Step examination scores are often used as a screening tool to discern candidates qualifying for residency interviews. As with any specialty, careful preparation for steps 1 and 2 to optimize scores is therefore advantageous.

\section{Preparing for residency application}

Once the decision to pursue neurology is made, students should identify a member of their neurology faculty to serve as a mentor. A close mentor who will write a positive, personalized LOR for the student based on directly observed or shared experiences is more important than a letter from a chairperson or program director who may not know the student well. The distinction is often apparent in review of a residency application. Residency programs typically require 3 LORs, at least 2 of which should be from neurology faculty. A solid LOR from a faculty member outside of neurology (e.g., internal medicine) is also well-received if it reflects familiarity with the student's skills and performance. If applicable, students should include an LOR from their research mentor. LOR writers should be given several months of advance notice. Students should meet with the neurology clerkship or program director at the home institution to discuss their career choice and obtain additional specialty-specific career and application tips. Currently, ERAS applications are accepted during the second week in September and applications should be completed prior to this date to have the best chance of securing competitive interviews (figure).

Two types of residency positions are offered by programs: categorical and advanced. Categorical adult neurology programs are 4 years in length and include the medicine internship year. Categorical child neurology programs are 5 years in length and include 2 years of pediatrics. Noncategorical or advanced neurology programs start after the general medical training and are not linked to the same institution's preliminary medicine internship (for adult neurology) or pediatrics training program (for child neurology). Students interested in advanced programs must apply separately for a preliminary internship program. The same pros and cons that would apply to any other specialty when considering these 2 types of residency positions hold true for neurology. We encourage students to discuss which type of residency is best for them with their academic faculty advisers.

\section{Discussion}

We have detailed a practical, longitudinal timeline and recommendations for medical students preparing for a career in neurology and specifically for the neurology residency application process. It is our hope that this article will be a useful resource for students interested in a career in neurology and educators who advise and mentor students in career choices. The timeline and recommendations outline a suggested, early approach and should not discourage students from considering neurology at a later point in their training. Neurology remains an inclusive specialty that welcomes students of all backgrounds and offers a rewarding career in one of the most exciting fields in medicine.

\section{Study funding}

No targeted funding reported.

\section{Disclosure}

The authors report no relevant disclosures. Go to Neurology. org/N for full disclosures.

\begin{tabular}{|c|c|c|}
\hline Author & Location & Contribution \\
\hline $\begin{array}{l}\text { James J. } \\
\text { Gugger, MD, } \\
\text { PharmD }\end{array}$ & $\begin{array}{l}\text { Johns Hopkins } \\
\text { University, Baltimore, } \\
\text { MD }\end{array}$ & $\begin{array}{l}\text { Edited and revised subsequent } \\
\text { drafts of the manuscript }\end{array}$ \\
\hline $\begin{array}{l}\text { Lauren } \\
\text { Bowen } \\
\text { Reoma, MD }\end{array}$ & NIH, Bethesda, MD & $\begin{array}{l}\text { Coauthored the first draft of the } \\
\text { manuscript, edited and revised } \\
\text { subsequent drafts of the } \\
\text { manuscript }\end{array}$ \\
\hline $\begin{array}{l}\text { Madhu Soni, } \\
\text { MD }\end{array}$ & $\begin{array}{l}\text { Rush University } \\
\text { Medical Center, } \\
\text { Chicago, IL }\end{array}$ & $\begin{array}{l}\text { Edited and revised subsequent } \\
\text { drafts of the manuscript }\end{array}$ \\
\hline $\begin{array}{l}\text { Valerie } \\
\text { Olson, MD, } \\
\text { PhD }\end{array}$ & $\begin{array}{l}\text { University of } \\
\text { Washington, Seattle }\end{array}$ & $\begin{array}{l}\text { Coauthored the first draft of the } \\
\text { manuscript }\end{array}$ \\
\hline $\begin{array}{l}\text { Ezgi Tiryaki, } \\
\text { MD }\end{array}$ & $\begin{array}{l}\text { University of } \\
\text { Minnesota, } \\
\text { Minneapolis }\end{array}$ & $\begin{array}{l}\text { Edited and revised subsequent } \\
\text { drafts of the manuscript }\end{array}$ \\
\hline $\begin{array}{l}\text { James M. } \\
\text { Noble, MD, } \\
\text { MS }\end{array}$ & $\begin{array}{l}\text { Columbia University } \\
\text { Medical Center, New } \\
\text { York, NY }\end{array}$ & $\begin{array}{l}\text { Edited and revised subsequent } \\
\text { drafts of the manuscript }\end{array}$ \\
\hline
\end{tabular}

\section{Appendix 2 Coinvestigators}

\begin{tabular}{|c|c|c|c|}
\hline Name & Location & Role & Contribution \\
\hline $\begin{array}{l}\text { Imran Ali, } \\
\text { MD }\end{array}$ & $\begin{array}{l}\text { University of } \\
\text { Toledo, } \mathrm{OH}\end{array}$ & $\begin{array}{l}\text { Chair, AAN } \\
\text { Undergraduate } \\
\text { Education } \\
\text { Subcommittee } \\
\text { (UES) }\end{array}$ & $\begin{array}{l}\text { Contributed ideas } \\
\text { and shared } \\
\text { experiences in } \\
\text { medical student } \\
\text { education }\end{array}$ \\
\hline $\begin{array}{l}\text { Jonathan } \\
\text { Carter, MD }\end{array}$ & $\begin{array}{l}\text { Mayo Clinic, } \\
\text { Phoenix, AZ }\end{array}$ & Member, UES & $\begin{array}{l}\text { Contributed ideas } \\
\text { and shared } \\
\text { experiences in } \\
\text { medical student } \\
\text { education }\end{array}$ \\
\hline $\begin{array}{l}\text { Charlene } \\
\text { Gamaldo, } \\
\text { MD }\end{array}$ & $\begin{array}{l}\text { Johns } \\
\text { Hopkins } \\
\text { University, } \\
\text { Baltimore, } \\
\text { MD }\end{array}$ & Member, UES & $\begin{array}{l}\text { Contributed ideas } \\
\text { and shared } \\
\text { experiences in } \\
\text { medical student } \\
\text { education }\end{array}$ \\
\hline $\begin{array}{l}\text { Chad Hales, } \\
\text { MD, PhD }\end{array}$ & $\begin{array}{l}\text { Emory } \\
\text { University, } \\
\text { Atlanta, GA }\end{array}$ & Member, UES & $\begin{array}{l}\text { Contributed ideas and } \\
\text { shared experiences in } \\
\text { medical student } \\
\text { education }\end{array}$ \\
\hline $\begin{array}{l}\text { Holli Ann } \\
\text { Horak, MD }\end{array}$ & $\begin{array}{l}\text { University of } \\
\text { Arizona, } \\
\text { Tucson }\end{array}$ & Member, UES & $\begin{array}{l}\text { Contributed ideas } \\
\text { and shared } \\
\text { experiences in } \\
\text { medical student } \\
\text { education }\end{array}$ \\
\hline
\end{tabular}




\section{Appendix 2 (continued)}

\begin{tabular}{|c|c|c|c|}
\hline Name & Location & Role & Contribution \\
\hline $\begin{array}{l}\text { Jeffrey } \\
\text { Kraakevik, } \\
\text { MD }\end{array}$ & $\begin{array}{l}\text { Oregon } \\
\text { Health and } \\
\text { Science } \\
\text { University, } \\
\text { Portland }\end{array}$ & Member, UES & $\begin{array}{l}\text { Contributed ideas } \\
\text { and shared } \\
\text { experiences in } \\
\text { medical student } \\
\text { education }\end{array}$ \\
\hline $\begin{array}{l}\text { Joseph } \\
\text { Safdieh, MD }\end{array}$ & $\begin{array}{l}\text { Weill Cornell } \\
\text { Medicine, } \\
\text { New York, NY }\end{array}$ & Member, UES & $\begin{array}{l}\text { Contributed ideas and } \\
\text { shared experiences in } \\
\text { medical student } \\
\text { education }\end{array}$ \\
\hline $\begin{array}{l}\text { Diane } \\
\text { Solomon, } \\
\text { MD }\end{array}$ & $\begin{array}{l}\text { UT Health } \\
\text { San Antonio, } \\
\text { TX }\end{array}$ & Member, UES & $\begin{array}{l}\text { Contributed ideas and } \\
\text { shared experiences in } \\
\text { medical student } \\
\text { education }\end{array}$ \\
\hline $\begin{array}{l}\text { James } \\
\text { Stankiewicz, } \\
\text { MD }\end{array}$ & $\begin{array}{l}\text { Brigham and } \\
\text { Women's } \\
\text { Hospital, } \\
\text { Boston, MA }\end{array}$ & Member, UES & $\begin{array}{l}\text { Contributed ideas and } \\
\text { shared experiences in } \\
\text { medical student } \\
\text { education }\end{array}$ \\
\hline $\begin{array}{l}\text { Lisa Merlin, } \\
\text { MD }\end{array}$ & $\begin{array}{l}\text { SUNY } \\
\text { Downstate } \\
\text { Medical } \\
\text { Center, } \\
\text { Brooklyn, NY }\end{array}$ & Member, UES & $\begin{array}{l}\text { Contributed ideas and } \\
\text { shared experiences in } \\
\text { medical student } \\
\text { education }\end{array}$ \\
\hline $\begin{array}{l}\text { Heidi } \\
\text { Woessner, } \\
\text { MD }\end{array}$ & $\begin{array}{l}\text { Piedmont } \\
\text { Healthcare, } \\
\text { Atlanta, GA }\end{array}$ & Member, UES & $\begin{array}{l}\text { Contributed ideas and } \\
\text { shared experiences in } \\
\text { medical student } \\
\text { education }\end{array}$ \\
\hline
\end{tabular}

\section{References}

1. National Resident Matching Program. Results and Data: 2019 Main Residency Match. Washington: National Resident Matching Program; 2019.

2. Merlin LR, Horak HA, Milligan TA, et al. A competency-based longitudinal core curriculum in medical neuroscience. Neurology 2014;83:456-462.

3. Safdieh JE, Quick AD, Korb PJ, et al. A dozen years of evolution of neurology clerkships in the United States: looking up. Neurology 2018;91:e1440-e1447.

4. Safdieh JE, Govindarajan R, Gelb DJ, et al. Core curriculum guidelines for a required clinical neurology experience. Neurology 2019;92:619-626.

5. Student Interest Group in Neurology (SIGN). Available at: aan.com/tools-andresources/medical-students/sign-toolkit/. Accessed September 19, 2019.

6. Zuzuarregui JR, Wu C, Hohler AD. Promoting careers in neurology: mentorship of medical students. Semin Neurol 2018;38:413-417.

7. Sozio SM, Pivert KA, Shah HH, et al. Increasing medical student interest in nephrology. Am J Nephrol 2019;50:4-10.

8. Schiess N, Saylor D, Zunt J. Global neurology: navigating career possibilities. Semin Neurol 2018;38:145-151.

9. Gilbert DL, Horn PS, Kang PB, et al. Child neurology recruitment and training: views of residents and child neurologists from the $2015 \mathrm{AAP} / \mathrm{CNS}$ workforce survey. Pediatr Neurol 2017;66:88-95. 


\section{Neurology}

\section{Residency Training: A practical guide for medical students who are planning a future in neurology}

James J. Gugger, Lauren Bowen Reoma, Madhu Soni, et al. Neurology 2020;94;673-677 Published Online before print March 12, 2020 DOI 10.1212/WNL.0000000000009247

This information is current as of March 12, 2020

Updated Information \&
Services
References
Citations
Subspecialty Collections
Permissions \& Licensing
Reprints

\section{Updated Information \&}

References

\section{Citations}

\section{Subspecialty Collections}

Reprints including high resolution figures, can be found at: http://n.neurology.org/content/94/15/673.full

This article cites 7 articles, 3 of which you can access for free at: http://n.neurology.org/content/94/15/673.full\#ref-list-1

This article has been cited by 1 HighWire-hosted articles: http://n.neurology.org/content/94/15/673.full\#\#otherarticles

This article, along with others on similar topics, appears in the following collection(s):

\section{All Education}

http://n.neurology.org/cgi/collection/all_education

Information about reproducing this article in parts (figures,tables) or in its entirety can be found online at:

http://www.neurology.org/about/about_the_journal\#permissions

Information about ordering reprints can be found online:

http://n.neurology.org/subscribers/advertise

Neurology $®$ is the official journal of the American Academy of Neurology. Published continuously since 1951 , it is now a weekly with 48 issues per year. Copyright @ 2020 American Academy of Neurology. All rights reserved. Print ISSN: 0028-3878. Online ISSN: 1526-632X.

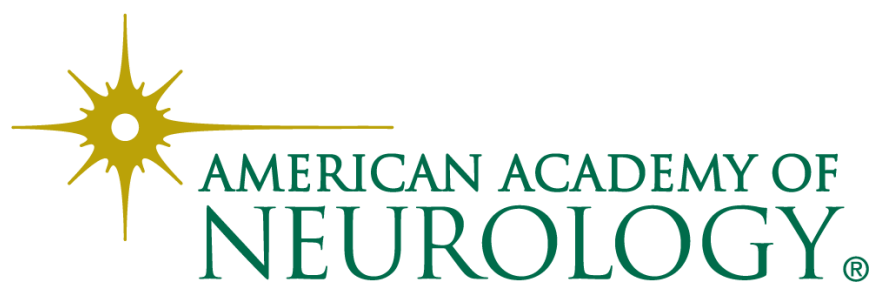

